\title{
СИНТЕЗ И БИОЛОГИЧЕСКАЯ АКТИВНОСТЬ ТРИТЕРПЕНОВЫХ 1,2,3,4-ТЕТРАЗОЛИЛПРОИЗВОДНЫХ
}

\begin{abstract}
А.В. Петрова' , Д.А. Бабков², Э.Ф. Хуснутдинова'
${ }^{1}$ Уфимский институт химии, Уфимский Исследовательский центр РАН, 450054, Россия, г. Уфа, проспект Октября, 69.

${ }^{2}$ Научный центр инновационных лекарственных средств, ФГБОУ ВО ВолгМУ Минздрава

России, 400131, Россия, г. Волгоград, площадь Павших Борцов, 1.

DOI: 10.19163/MedChemRussia2021-2021-300

E-mail: ana.orgchem@gmail.com

Получена новая серия производных тритерпеноидов и стероидов, содержащих тетразольный заместитель в ключевых С2, C3 и С12 положениях. Синтез осуществляли путем взаимодействия соответствующих им цианопроизводных с азидом натрия в ДМФА при кипячении в присутствии NaOAc. B случае синтеза соединений 2 и 5, реакция проходила хемоселективно с образованием моно-тетразолилпроизводных, что возможно объяснить стерически затрудненным положением С28 соединения 5, и влияния второй цианоэтильной группы в соединении 2. Строение полученных производных установлено с использованием ЯМР ${ }^{1} \mathrm{H}$ и ${ }^{13} \mathrm{C}$ спектроскопии. Ориентация циано- и тетразолэтильного заместителей для соединения 2 была установлена на основании данных NOESY спектра, где наблюдаются кросс-пики для метиленовых протонов при С35 ( $\delta \mathrm{H} 2.33$ и 2.42 м.д.) с сигналом C25-метильной группы ( $\delta \mathrm{H} 0.73$ м.д.), что указывает на $\beta$-ориентацию цианоэтильного заместителя. Для тетразолэтильного заместителя наблюдаются NOE кросс-пики сигналов HB-31 ( $\delta \mathrm{H} 2.43$ м.д.) и НА-32 ( $\delta \mathrm{H} 2.68$ м.д.) с сигналом $\alpha$-ориентированной метильной группы C23 при $\delta \mathrm{H} 1.18$ м.д., что также подтверждает (R)-конфигурацию C2 хирального центра.
\end{abstract}

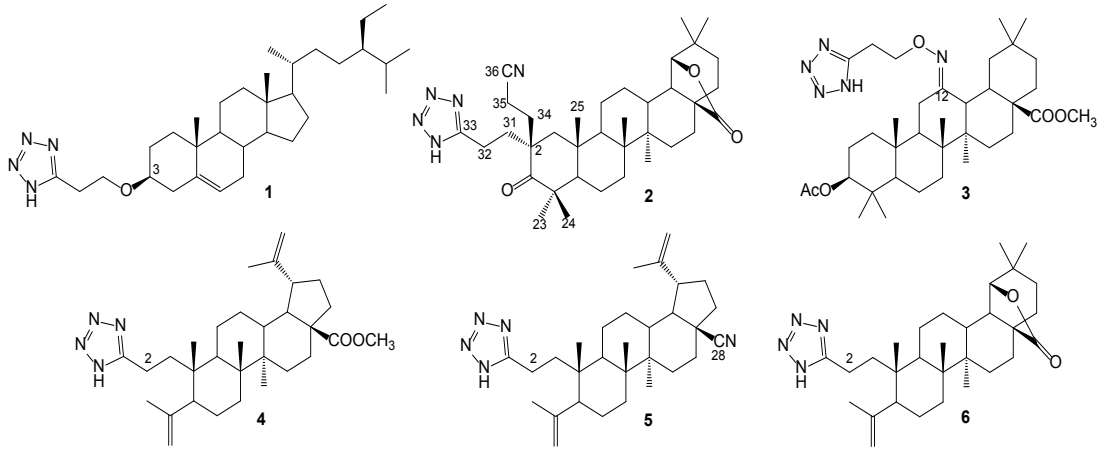

Полученные соединения исследовали на противоопухолевую и антидиабетическую активность in vitro. Соединение 4 продемонстрировало цитостатические свойства в отношении клеточной линии рака простаты $\left(\mathrm{GI}_{50} 3.46 \mu \mathrm{M}\right)$, в то время как соединение 1 ингибировало фермент $\alpha$-глюкозидазу почти в 5000 раз эффективнее $\left(\mathrm{IC}_{50} 0.04 \mu \mathrm{M}\right)$ чем препарат сравнения акарбоза (IC $\left.\mathrm{C}_{50} 189 \mu \mathrm{M}\right)$.

$$
-300-
$$

